\title{
Precipitation of Calcium Oxalate Monohydrate Under Nearly the Same Initial Supersaturation
}

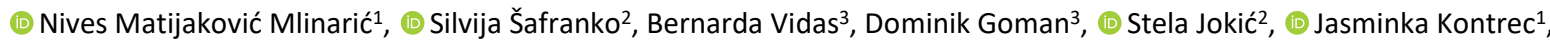
(1) Branka Njegić Džakula ${ }^{1}$, (1) Ida Delač Marion ${ }^{4}$, (1) Martina Medvidović-Kosanović ${ }^{3}$, (ㄱ) Anamarija Stanković3,*

\footnotetext{
1 Ruđer Bošković Institute, Bijenička cesta 54, 10000 Zagreb, Croatia

2 Faculty of Food Technology Osijek, Josip Juraj Strossmayer University of Osijek, Franje Kuhača 18, 31000 Osijek, Croatia

3 Department of Chemistry, Josip Juraj Strossmayer University of Osijek, Cara Hadrijana 8/A, 31000 Osijek, Croatia

${ }^{4}$ Center of Excellence for Advanced Materials and Sensing Devices, Institute of Physics, Bijenička cesta 46, 10000 Zagreb, Croatia

* Corresponding author's e-mail address: astankovic@kemija.unios.hr
}

RECEIVED: June 25, 2021 * REVISED: September 13, 2021 * ACCEPTED: September 14, 2021

\begin{abstract}
Spontaneous precipitation of calcium oxalate monohydrate (COM) in additive-free systems with nearly the same initial supersaturation has been investigated. The influence of thermodynamic parameters such as: temperature $\left(t=25,36.5\right.$ and $\left.48{ }^{\circ} \mathrm{C}\right)$, calcium concentration range of $5 \mathrm{mmol} \mathrm{dm}^{-3} \leq \mathrm{c}_{\mathrm{i}}\left(\mathrm{Ca}^{2+}\right) \leq 10 \mathrm{mmol} \mathrm{dm}^{-3}$ and $\mathrm{pH}(5.6,6.5$ and 7.5$)$, on the potential changes in structure, morphology and crystal size of COM have been studied. The values of the initial parameters were varied in a wide range and included values relevant for mimicking the physiological conditions related to those in biological systems and kidney stone formation. The results contributed to the knowledge about the influence of the selected individual parameters as well as their interplay influence on in vitro precipitation of COM. The findings have indicated that COM was the only precipitated phase exhibiting predominant dendritic morphology. The effects on crystal size, structure and morphology are more pronounced at higher temperature, $\mathrm{pH}$ and calcium concentration. These results provide basis for future studies of overall mechanism of COM formation and the future studies of kidney stone prevention.
\end{abstract}

Keywords: calcium oxalate monohydrate, thermodynamic parameters, crystal size and morphology, supersaturation.

\section{INTRODUCTION}

B IOMINERALIZATION is a process by which a living organism manufactures minerals for different functional purposes, such as magnetic or gravitational sensing, mechanical stiffening of tissue and element storage. The biomineralization process involves the selective separation of inorganic and organic constituent units from the organism and their incorporation into functional superstructures. ${ }^{[1]}$ As opposed to biomineralization defined as a process in which new and functional materials are created, there is also pathological biomineralization which is a process of unwanted biomineral formation. ${ }^{[2]}$

A phenomenon of pathological biomineralization could be defined as an undesirable crystallization process of slightly soluble inorganic salts in soft tissues. Urolithiasis is a specific form of pathological biomineralization, that through series of processes involving nucleation, crystal growth and aggregation, leads to the formation of stones in different parts of the urinary tract. ${ }^{[3]}$ The formation of stones is a complex process influenced by multiple factors, but the exact mechanism is poorly understood. The formed crystals in patients usually differ in size, morphology, and/or crystal phase due to the differences in the concentration of calcium and oxalate ions, in the content of inhibitors and promoters among individuals ${ }^{[4,5]}$, or could be affected by the $\mathrm{pH}$ of media. It is noteworthy to mention that the incidence of kidney stones is constantly growing, especially in industrialized countries because of modern and accelerated lifestyles. ${ }^{[6]}$

The calcium oxalates can precipitate in the form of three hydrate modifications, thermodynamically stable calcium oxalate monohydrate (COM), metastable calcium oxalate dihydrate (COD) and calcium oxalate trihydrate (COT). In terms of Ostwald's rule of stages and at temperature $37^{\circ} \mathrm{C}$, COT $\left(K_{\text {sp }}=7.19 \times 10^{-9}\right)$ as the most 
soluble and least stable phase will form first, followed by $\operatorname{COD}\left(K_{\mathrm{sp}}=4.95 \times 10^{-9}\right)$, and then $\operatorname{COM}\left(K_{\mathrm{sp}}=2.28 \times 10^{-9}\right) \cdot{ }^{[7]}$

The COM and COD are predominantly present in the kidney stone composition. ${ }^{[8]}$ The COM is considered as the most common, the least soluble phase ${ }^{[9-11]}$ and more pathogenic for kidney stone formation due to its higher adhesive capability. ${ }^{[12]}$ Studies have shown that COM was the dominant precipitated phase and the crystal morphology was affected by the variations in concentration, $\mathrm{pH}$ value of media and temperature of the investigated systems. [13-15]

Moreover, different metabolic disorders (such as hyperoxaluria, hypercalciuria, hypocitraturia, and changes in the acidity of the urine) are crucial risk factors predisposing the oxalate stone formation. Primarily, hyperoxaluria will be diagnosed if the excretion of the 24hour urinary oxalate exceeds the upper limit of reference values $(0.22-0.44 \mathrm{mmol})$. Recent studies provided evidence of hyperoxaluria-induced oxidative stress. Oxalate ions and calcium oxalate crystals induce damage to renal tubular cells through the generation of reactive oxygen species and lipid peroxidation processes. ${ }^{[16]}$ Furthermore, hypercalciuria is a metabolic disorder of increased excretion of calcium in the urine. Hypercalciuria may decrease the activity of calcium salt crystallization inhibitors due to their binding to calcium ions. It is an important factor that influences the formation of calcium stones by increasing the concentration of calcium in the urine. Interestingly, hydrate phase COM could be found in most stones formed in the urinary system of patients with urolithiasis. ${ }^{[17]}$ Furthermore, the morphology and the shape of crystal particles in normal human urine are characterized as spherical or elliptical, whereas sharp corners and edges could be found in the urine of stone formers. These irregularly shaped crystals have a higher affinity to adhere to renal tubular epithelial cells and induce inflammation and physical damage to the tissue. ${ }^{[4]}$

The $\mathrm{pH}$ of urine is a very important risk factor for developing urinary stone disease. The urine of a healthy individual is normally considered as slightly acidic $(\mathrm{pH}=$ $6.0-6.5)$, but it can vary between acidic $(\mathrm{pH}=4.5)$ and alkaline $(\mathrm{pH}=8.0)$ over a period of 24-hour depending on the diet, the presence of infections/chronic diseases, or timing of sample collection. ${ }^{[9]}$ The presence of significant amounts of inorganic and organic ions gives the average ionic strength of urine about $0.33 \mathrm{~mol} \mathrm{dm}^{-3}$. Changes in urine $\mathrm{pH}$ may contribute to the formation of certain stone types. According to recent statistics, about $70 \%$ of kidney stones are composed of crystalline calcium oxalate. ${ }^{[17,18]}$

In this work, our primary goal was to synthesize COM under the conditions of the same initial calcium oxalate supersaturation and without the presence of additives. The effect of the following experimental parameters was explored: the $\mathrm{pH}$ (which was adjusted to mimic the $\mathrm{pH}$ of biological systems), the reactant calcium and oxalate concentrations and the system temperature. The calcium concentration was chosen to mimic normal and hypercalciuria conditions, while the initial oxalate concentration mimicked conditions of hyperoxaluria. The findings could demonstrate the relationship between the thermodynamic parameters and the structural characteristics of synthesized COM, which may be promising in vitro model for future studies of calcium oxalate crystal growth and the overall mechanism of crystal COM formation.

\section{EXPERIMENTAL SECTION}

\section{Materials}

Analytically pure chemicals, $\mathrm{CaCl}_{2} \cdot 2 \mathrm{H}_{2} \mathrm{O}$ (BDH Prolabo), $\mathrm{Na}_{2} \mathrm{C}_{2} \mathrm{O}_{4}$ (BDH Prolabo), $\mathrm{NaOH}$ (Gram-Mol), $\mathrm{HCl}$ (Gram-Mol) and pure deionized water (conductivity $\leq 0.055 \mu \mathrm{S} \mathrm{cm}^{-1}$ ) were used to prepare stock solutions. Both reactant solutions, $\mathrm{Ca}^{2+}$ solution and $\mathrm{C}_{2} \mathrm{O}_{4}{ }^{2-}$, were prepared by diluting the appropriate amount of $\mathrm{CaCl}_{2}$ or $\mathrm{Na}_{2} \mathrm{C}_{2} \mathrm{O}_{4}$ stock solutions, respectively. $\mathrm{NaOH}$ and $\mathrm{HCl}$ stock solutions were also prepared and used for the adjustment of the $\mathrm{pH}$ of the systems. All stock solutions were standardized according to classical analytical methods $\left(\mathrm{Na}_{2} \mathrm{C}_{2} \mathrm{O}_{4}\right.$ was standardized by titration with permanganate, $\mathrm{CaCl}_{2}$ by complexometric titration with EDTA, $\mathrm{NaOH}$ by volumetric titration with standard $\mathrm{HCl}$ and $\mathrm{HCl}$ by volumetric titration with standard $\mathrm{NaOH}$ ).

\section{Precipitation experiments}

The procedure for calcium oxalate precipitation was discussed in detail previously. $[14,19,20]$ The precipitation experiments were carried out in a thermostated, doublewalled glass reactor. Before initiating the experiments, reactant solutions were thermostated at the corresponding temperature (the process was carried out at $25^{\circ} \mathrm{C}, 36.5^{\circ} \mathrm{C}$, and $48^{\circ} \mathrm{C}$ ). The experiments were started by mixing equal volumes $\left(200 \mathrm{~cm}^{3}\right)$ of calcium and oxalate reactant solutions. The initial concentration of $\mathrm{C}_{2} \mathrm{O}_{4}{ }^{2-}$ was the same $\left(\mathrm{c}_{\mathrm{i}}\left(\mathrm{C}_{2} \mathrm{O}_{4}{ }^{2-}\right)=4 \mathrm{mmol} \mathrm{dm}^{-3}\right)$ throughout the experiments, while the initial concentration of $\mathrm{Ca}^{2+}$ was set within the concentration range of $5 \mathrm{mmol} \mathrm{dm}^{-3} \leq \mathrm{c}_{\mathrm{i}}\left(\mathrm{Ca}^{2+}\right) \leq 10 \mathrm{mmol} \mathrm{dm}^{-3}$. The $\mathrm{pH}$ of both reactant solutions was previously adjusted to corresponding values $(\mathrm{pH}=5.6,6.5$ or 7.5$)$ by the addition of $\mathrm{NaOH}$ or $\mathrm{HCl}$ standards.

A combined glass electrode, connected to a $\mathrm{pH}$ meter (HANNA HI 5522) was used to monitor the $\mathrm{pH}$ of the investigated systems and also to follow the progress of precipitations. The precipitation systems were continuously stirred using a Teflon-coated magnetic stirring bar. 
After an overall 20 min the obtained suspensions have been filtered through a $0.22 \mu \mathrm{m}$ membrane filter. The precipitates were washed with small portions of pure water and were finally dried in a vacuum desiccator. All precipitation experiments were performed in triplicate $(n=3)$ and the mean values of the obtained results are presented.

\section{Sample Characterization}

To determine the presence of individual hydrate phases in precipitated systems, infrared spectroscopy (FT-IR), powder X-ray diffraction (PXRD) and thermogravimetric analysis (TGA) were employed.

Thermogravimetric analysis (TGA) has been applied to determine the weight fraction of individual hydrate form in the samples using a simultaneous TGA-DSC analyzer (Mettler Toledo TGA/DSC 1). The weighted samples (up to $15 \mathrm{mg}$ ) were placed in the aluminum pan $(100 \mu \mathrm{L})$ and subjected to heating up to $300{ }^{\circ} \mathrm{C}$ at a heating rate of $2{ }^{\circ} \mathrm{C}$ $\mathrm{min}^{-1}$ in the oxygen atmosphere. Finally, data collection and interpretation were performed by using STARe Software 10.0. package.

The composition and crystallinity were investigated by X-ray diffraction on the polycrystalline sample (XRD) on Aeris Panalytical diffractometer with $\mathrm{Ni}$-filtered copper radiation, in Bragg-Brentano geometry in the range $5^{\circ} \leq 2 \theta$ $\leq 60^{\circ}$ (step size $0.02^{\circ}$ ). Calcium oxalate monohydrate (COM) was identified according to the ICDD Powder Diffraction Files 01-075-1313 (space group $P 2_{1} / c$, unit cell parameters: $a=9.97 \AA, b=14.58 \AA$ and $c=6.29 \AA$ ) . The precipitated samples were placed on a silicon zero-background sample holder. The obtained diffraction pattern was analysed by the PANalytical High Score Plus software.

The transmission infrared (IR) spectra of dried samples were recorded from $4000 \mathrm{~cm}^{-1}$ to $400 \mathrm{~cm}^{-1}$ at a spectral resolution of $4 \mathrm{~cm}^{-1}$ by means of Shimadzu FTIR 8400 spectrophotometer equipped with DRS 8000 attachment. The samples were prepared for the analysis by mixing a dry $\mathrm{KBr}$ (IR grade) with a small amount of sample (approximate ratio sample and $\mathrm{KBr} 1: 100)$.

The morphological characteristics and approximate crystal size of obtained precipitates were determined by a light microscope (Motic B1 with digital camera Moticam 2) and scanning electron microscope - SEM (Tescan Vega3 LMU with tungsten filament at $10 \mathrm{~mm}$ working distance, 5$30 \mathrm{kV}$ acceleration voltage). For imaging with SEM a small amount of dried sample (except samples $5 a$ and $5 c$ where a droplet of solution was used) was put on a sample holder covered with carbon tape and the excess powder was removed with the stream of nitrogen gas.

\section{Data Analysis}

The calculations of molar concentrations, activities of the relevant ionic species, the respective protolithic equilibria and equilibrium constants, as well as the charge and mass balance equations and the initial supersaturation, have been performed using the algorithm discussed previously in detail[13,21] or by VMINTEQ 3.1 (freely available at https://vminteq.Iwr.kth.se/). The supersaturation was expressed as the saturation ratio, $S$, defined as the square root of the quotient of the calcium oxalate monohydrate ion activity product, $\Pi=a\left(\mathrm{Ca}^{2+}\right) \cdot a\left(\mathrm{C}_{2} \mathrm{O}_{4}{ }^{2-}\right)$, and thermodynamic equilibrium constant of dissolution of the calcium oxalate monohydrate, $K_{\mathrm{sp}}{ }^{0}: S_{\mathrm{COM}}=\left(\Pi / K_{\mathrm{sp}}{ }^{0}\right)^{1 / 2}$

The initial concentration of reactants $\left(c_{\mathrm{i}}\right)$, respective temperatures $(t)$, initial $\mathrm{pH}$, calculated initial saturation ratios for COM (SСOM) and ionic strength $\left(I_{c}\right)$ in the precipitation systems are shown in Table 1 . Initial supersaturations were calculated for all precipitation systems, as can be seen from Table 1. The calculated values were nearly the same in the whole investigated range of the initial calcium concentration, $5.0 \leq \mathrm{c}_{\mathrm{i}}\left(\mathrm{Ca}^{2+}\right) / \mathrm{mmol} \mathrm{dm}^{-3} \leq$ 10.0, initial $\mathrm{pH}(5.6 \leq \mathrm{pH} \leq 7.5)$ and temperature $25.0 \leq$ $t /{ }^{\circ} \mathrm{C} \leq 48.0$, i.e. $S_{\mathrm{COM}}=30.73 \pm 2.08$. Initial supersaturation in these systems, under given experimental conditions, is relatively high, so that the difference of three units between systems is not significant and supersaturation might be considered nearly the same. Based on this, systems were chosen for precipitation experiments, and these systems are marked in orange.

\section{RESULTS AND DISCUSSION}

In this paper, the influence of the temperature $(t)$, initial concentrations of the reactants and the initial $\mathrm{pH}$ of the systems on the spontaneously precipitated calcium oxalate monohydrate (COM), at nearly the same initial supersaturations, was investigated. It is well-known that COM is the most common constituent of kidney stones, so the study of the synthesis of COM and the relationship between the thermodynamic parameters, precipitation predisposition and morphological characteristics of the obtained precipitate is of great importance for understanding the possible mechanisms of the formation of kidney stones.

\section{The Structural Analysis}

Phase identification and structural analysis of the individual samples in investigated systems were carried out by thermogravimetric analysis (TGA), infrared spectroscopy (Fourier-transform infrared spectroscopy; FT-IR) and powder X-ray diffraction (PXRD). The results demonstrated that the solid phase identified in all investigated precipitation systems was exclusively COM.

As shown in Table 2, the TGA indicated the presence of COM hydrate in the samples, exclusively. Theoretical weight losses in TGA for crystalline water in pure COM is 
Table 1. Precipitation system, initial concentration of reactants $\left(c_{\mathrm{i}}\right)$, temperature $(t)$, initial $\mathrm{pH}$. Initial saturation ratios with respect to $\mathrm{COM}\left(\mathrm{S}_{\mathrm{COM}}\right)$ and ionic strength $\left(I_{c}\right)$ are calculated values. The systems used for precipitation experiments are highlighted in orange

\begin{tabular}{|c|c|c|c|c|c|c|c|c|c|}
\hline & & & & \multicolumn{3}{|c|}{$\mathrm{pH}$} & \multicolumn{3}{|c|}{$\mathrm{pH}$} \\
\hline \multicolumn{4}{|c|}{ Precipitation Systems } & a & $b$ & c & a & $b$ & c \\
\hline & & & & 5.6 & 6.5 & 7.5 & 5.6 & 6.5 & 7.5 \\
\hline No. & $\mathrm{C}_{\mathrm{i}}\left(\mathrm{Ca}^{2+}\right)$ & $\mathrm{C}_{\mathrm{i}}\left(\mathrm{C}_{2} \mathrm{O}_{4}{ }^{2-}\right)$ & $t$ & \multicolumn{3}{|c|}{ Sсом } & \multicolumn{3}{|c|}{$I_{c}$} \\
\hline \multicolumn{3}{|c|}{$\mathrm{mmol} \mathrm{dm} \mathrm{m}^{-3}$} & ${ }^{\circ} \mathrm{C}$ & & & & \multicolumn{3}{|c|}{$\mathrm{mol} \mathrm{dm}{ }^{-3}$} \\
\hline 1 & 5.0 & & & 28.91 & 29.04 & 29.04 & 0.018 & 0.018 & 0.018 \\
\hline 2 & 7.5 & 4.0 & 25.0 & 31.41 & 31.51 & 31.51 & 0.023 & 0.023 & 0.023 \\
\hline 3 & 10.0 & & & 32.70 & 32.77 & 32.81 & 0.030 & 0.030 & 0.030 \\
\hline 4 & 5.0 & & & 28.77 & 28.91 & 28.94 & 0.018 & 0.018 & 0.018 \\
\hline 5 & 7.5 & 4.0 & 36.5 & 31.26 & 31.41 & 31.41 & 0.023 & 0.023 & 0.023 \\
\hline 6 & 10.0 & & & 32.55 & 32.66 & 32.66 & 0.030 & 0.030 & 0.030 \\
\hline 7 & 5.0 & & & 28.64 & 28.81 & 28.81 & 0.018 & 0.018 & 0.018 \\
\hline 8 & 7.5 & 4.0 & 48.0 & 31.12 & 31.26 & 31.30 & 0.024 & 0.023 & 0.023 \\
\hline 9 & 10.0 & & & 32.40 & 32.55 & 32.55 & 0.030 & 0.030 & 0.030 \\
\hline
\end{tabular}

Table 2. Results of the thermogravimetric analysis of the samples ( $t_{0}$ - initial degradation temperature, $t_{\max }$ - temperature of maximum degradation rate, $t_{\mathrm{e}}$ - end of degradation temperature)

\begin{tabular}{|c|c|c|c|c|c|}
\hline \multirow{2}{*}{\multicolumn{2}{|c|}{$\begin{array}{l}\text { Precipitation } \\
\text { Systems* }\end{array}$}} & \multicolumn{3}{|c|}{$1^{\text {st }}$ step } & \multirow{2}{*}{$\frac{\text { Total mass loss }}{\Delta m / \%}$} \\
\hline & & $t_{0} /{ }^{\circ} \mathrm{C}$ & $t_{\max } /{ }^{\circ} \mathrm{C}$ & $t_{\mathrm{e}} /{ }^{\circ} \mathrm{C}$ & \\
\hline & 1 & 69.05 & 143.90 & 199.45 & 11.60 \\
\hline & $2 a$ & 69.00 & 142.61 & 201.55 & 11.52 \\
\hline & $2 b$ & 68.23 & 145.23 & 196.30 & 11.43 \\
\hline & $2 c$ & 65.42 & 142.91 & 201.39 & 11.83 \\
\hline & 3 & 70.50 & 143.97 & 197.32 & 11.25 \\
\hline & 4 & 68.94 & 146.90 & 194.94 & 11.60 \\
\hline & $5 a$ & 66.58 & 144.08 & 196.95 & 11.77 \\
\hline & $5 b$ & 69.65 & 145.54 & 196.44 & 11.93 \\
\hline & $5 c$ & 68.08 & 143.95 & 195.72 & 11.93 \\
\hline & 6 & 70.54 & 144.26 & 196.88 & 11.78 \\
\hline & 7 & 69.18 & 147.28 & 196.44 & 11.57 \\
\hline & $8 a$ & 69.83 & 143.86 & 197.45 & 11.48 \\
\hline & $8 b$ & 69.76 & 146.90 & 196.17 & 11.62 \\
\hline & $8 c$ & 63.16 & 142.76 & 196.40 & 11.79 \\
\hline & 9 & 69.43 & 143.14 & 196.23 & 11.88 \\
\hline \multicolumn{6}{|c|}{$\begin{array}{l}\text { * These are the same precipitation systems as in Table } 1 \text {. The systems } \\
\text { highlighted in orange were used for futher quantitative analysis: }\end{array}$} \\
\hline \multicolumn{6}{|c|}{$\begin{array}{l}5 \mathrm{a} ; t=36.5^{\circ} \mathrm{C}, c_{\mathrm{i}}\left(\mathrm{Ca}^{2+}\right)=7.5 \mathrm{mmol} \mathrm{dm}^{-3}, c_{\mathrm{i}}\left(\mathrm{C}_{2} \mathrm{O}_{4}{ }^{2-}\right)=4.0 \mathrm{mmol} \mathrm{dm}^{-3} \\
\mathrm{pH}=5.6\end{array}$} \\
\hline \multicolumn{6}{|c|}{$\begin{array}{l}5 \mathrm{~b} ; t=36.5^{\circ} \mathrm{C}, c_{\mathrm{i}}\left(\mathrm{Ca}^{2+}\right)=7.5 \mathrm{mmol} \mathrm{dm}^{-3}, c_{\mathrm{i}}\left(\mathrm{C}_{2} \mathrm{O}_{4}{ }^{2-}\right)=4.0 \mathrm{mmol} \mathrm{dm}^{-3}, \\
\mathrm{pH}=6.5\end{array}$} \\
\hline \multicolumn{6}{|c|}{$\begin{array}{l}5 \mathrm{c} ; t=36.5^{\circ} \mathrm{C}, \mathrm{c}_{\mathrm{i}}\left(\mathrm{Ca}^{2+}\right)=7.5 \mathrm{mmol} \mathrm{dm}^{-3}, \mathrm{c}_{\mathrm{i}}\left(\mathrm{C}_{2} \mathrm{O}_{4}{ }^{2-}\right)=4.0 \mathrm{mmol} \mathrm{dm}^{-3}, \\
\mathrm{pH}=7.5\end{array}$} \\
\hline
\end{tabular}

$12.33 \%{ }^{[22]}$ The thermogram of sample $5 b$, as representative, is shown in Figure 1. It can be seen that the loss of one molecule of water takes place in only one step and the mass loss was $11.93 \%$. Table data of all precipitated samples (presented in Table 2) have indicated that weight loss has started at approximately $68.49 \pm 2.05^{\circ} \mathrm{C}$ (inflection point at $144.48 \pm 2.79{ }^{\circ} \mathrm{C}$ ). Total weight loss of samples, occurring after sample heating $300{ }^{\circ} \mathrm{C}$, was found to be about $11.66 \pm 0.26 \%$, corresponding to approximately one crystalline water molecule in COM. ${ }^{[22]}$

The orange color in Table 2 highlights the systems 5a, $5 b$ and $5 c$ (systems with nearly the same initial supersaturation $\left(S_{C O M}=30.73 \pm 2.08\right)$, temperature $\left(t=36.5^{\circ} \mathrm{C}\right)$ and initial reactant concentrations $\left(c_{\mathrm{i}}\left(\mathrm{Ca}^{2+}\right)=7.5 \mathrm{mmol} \mathrm{dm}^{-3}\right.$, $\left.c_{\mathrm{i}}\left(\mathrm{C}_{2} \mathrm{O}_{4}{ }^{2-}\right)=4.0 \mathrm{mmol} \mathrm{dm}^{-3}\right)$ with variations in the systems $\mathrm{pH}$ (system $5 \mathrm{a}$ at $\mathrm{pH}=5.6$, system $5 \mathrm{~b}$ at $\mathrm{pH}=6.5$ and system $5 \mathrm{c}$ at $\mathrm{pH}=7.5$ ). These precipitation systems have been selected for further quantitative analysis, as the samples were obtained under conditions that could be closely compared to those in biological systems.

For the qualitative analysis of COM, the IR spectra (Figure 2) of the obtained samples were compared with literature data of reference COM.[15]

It could be seen from Figure 2 that all the spectra show the IR bands specific for COM. Typical IR transmittance bands of $\mathrm{COM}$ are designated as: five peaks above $3000 \mathrm{~cm}^{-1}$ (near $3486 \mathrm{~cm}^{-1}, 3433 \mathrm{~cm}^{-1}, 3330 \mathrm{~cm}^{-1}, 3245 \mathrm{~cm}^{-1}$, and $3061 \mathrm{~cm}^{-1}$ ) assigned to $\mathrm{OH}$ stretching, the sharp asymmetric stretching peak $\mathrm{C}=\mathrm{O}$ at $1620 \mathrm{~cm}^{-1}$, stretching symmetric peak $\mathrm{C}=\mathrm{O}$ at $1317 \mathrm{~cm}^{-1}$, vibrations at $948 \mathrm{~cm}^{-1}$ and $885 \mathrm{~cm}^{-1}$ assigned to $\mathrm{C}-\mathrm{C}$ stretching, out-of-plane bending 


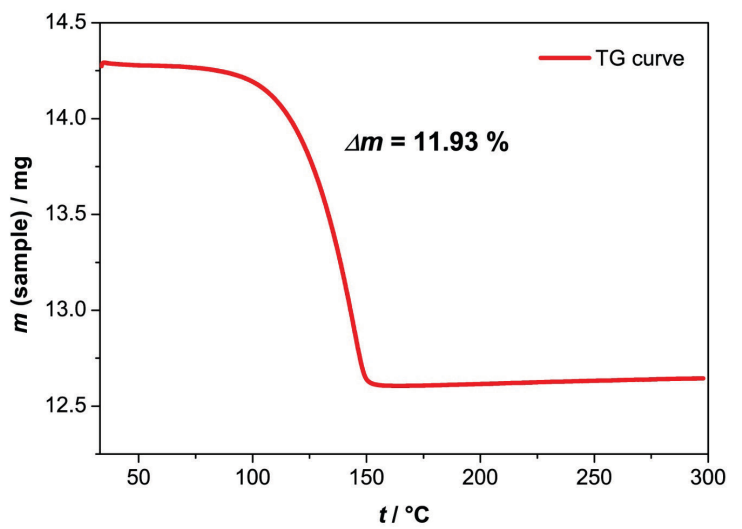

Figure 1. TGA curve of calcium oxalate sample isolated from the $5 \mathrm{~b}$ system $\left(\mathrm{S}_{\mathrm{COM}}=30.73 \pm 2.08, t=36.5^{\circ} \mathrm{C}, \mathrm{pH}=6.5\right.$ and $\left.\mathrm{c}_{\mathrm{i}}\left(\mathrm{Ca}^{2+}\right)=7.5 \mathrm{mmol} \mathrm{dm}^{-3}, \mathrm{c}_{\mathrm{i}}\left(\mathrm{C}_{2} \mathrm{O}_{4}{ }^{2-}\right)=4.0 \mathrm{mmol} \mathrm{dm}^{-3}\right)$.

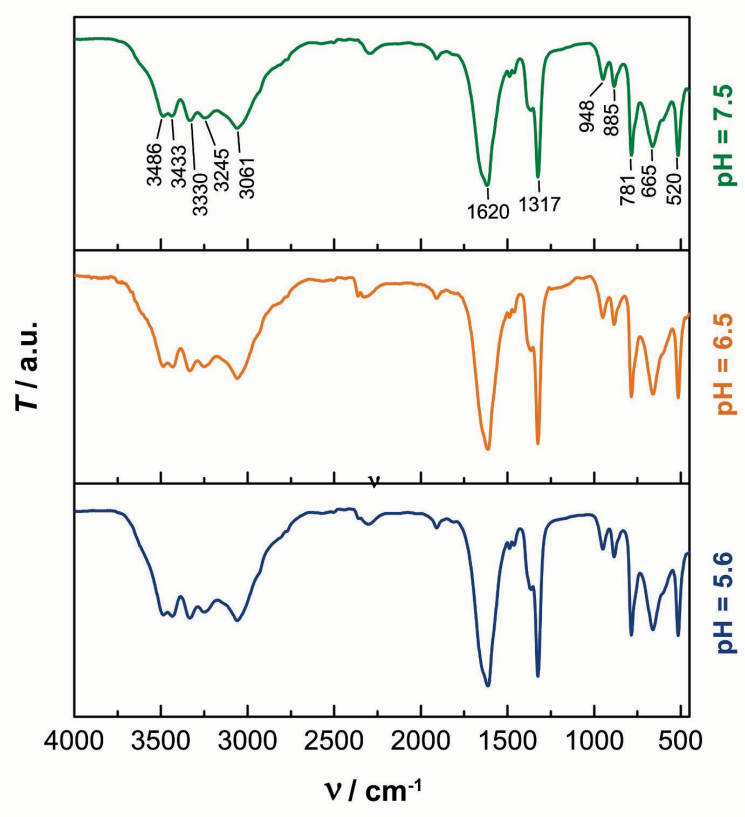

Figure 2. IR spectra of the samples isolated from the precipitation systems with nearly the same initial supersaturation, reactant concentrations $\left(c_{i}\left(\mathrm{Ca}^{2+}\right)=7.5\right.$ $\mathrm{mmol} \mathrm{dm}{ }^{-3}$ and $\left.\mathrm{c}_{\mathrm{i}}\left(\mathrm{C}_{2} \mathrm{O}_{4}{ }^{2-}\right)=4.0 \mathrm{mmol} \mathrm{dm}^{-3}\right)$ and temperature $\left(t=36.5^{\circ} \mathrm{C}\right)$ but different initial $\mathrm{pH}: \mathrm{pH}=5.6$ for $5 \mathrm{a}$ (blue), $\mathrm{pH}=6.5$ for $5 \mathrm{~b}$ (orange) and $\mathrm{pH}=7.5$ for $5 \mathrm{c}$ (green). The typical wavenumbers (in $\mathrm{cm}^{-1}$ ) of COM are denoted.

of water at $781 \mathrm{~cm}^{-1}$, vibration at $665 \mathrm{~cm}^{-1} \mathrm{H}_{2} \mathrm{O}$ vibration mode and band at $520 \mathrm{~cm}^{-1}$ assigned to $\mathrm{Ca}-\mathrm{O}$ stretching. ${ }^{[15]}$ The PXRD (Figure $3 \mathrm{~A}$ ) was employed for qualitative structural analysis of COM.

In the PXRD patterns of the samples $5 a, 5 b$ and $5 c$ (Figure $3 \mathrm{~A}$ ), isolated from the experiments in which initial supersaturation was nearly the same for all the systems and
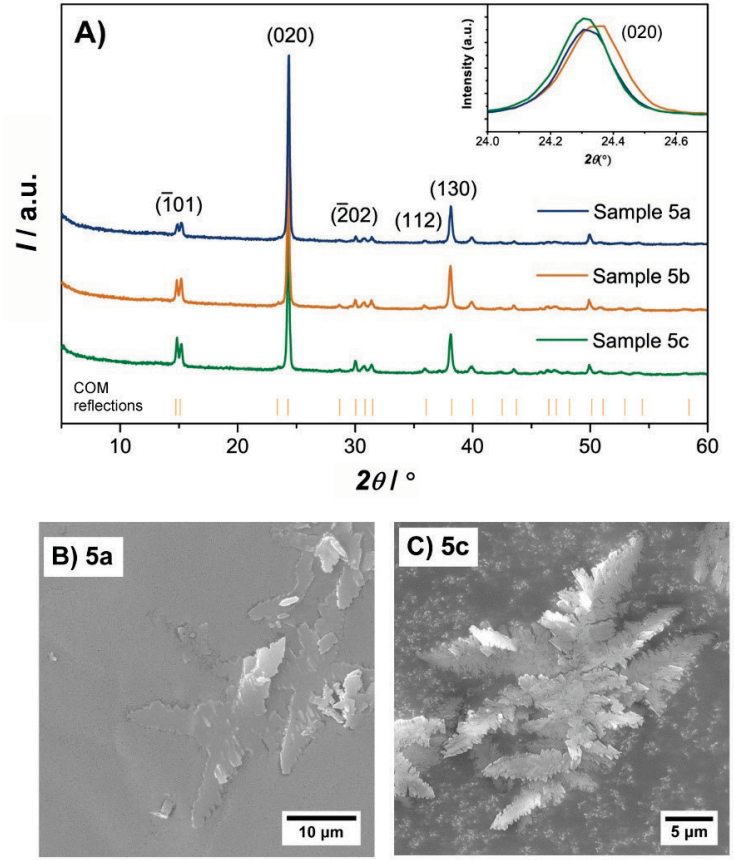

Figure 3. (A) XRD patterns of the samples isolated from the precipitation systems $(5 a, 5 b, 5 c)$ with nearly the same initial supersaturation $\left(S_{C O M}=30.73 \pm 2.08\right)$ reactant concentrations $\left(c_{i}\left(\mathrm{Ca}^{2+}\right)=7.5 \mathrm{mmol} \mathrm{dm}{ }^{-3}\right.$ and $c_{\mathrm{i}}\left(\mathrm{C}_{2} \mathrm{O}_{4}{ }^{2-}\right)=4.0$ mmol dm${ }^{-3}$ ) and temperature $\left(t=36.5{ }^{\circ} \mathrm{C}\right.$ ) but different initial $\mathrm{pH}$ : $\mathrm{pH}=5.6$ for $5 \mathrm{a}$ (blue), $\mathrm{pH}=6.5$ for $5 \mathrm{~b}$ (orange) and $\mathrm{pH}=7.5$ for $5 \mathrm{c}$ (green). Standard diffraction reflections and typical planes of COM are denoted. Inset: (020) diffraction peaks of the samples $5 a, 5 b$ and $5 c$. SEM images of the $5 a$ (B) and $5 \mathrm{c}$ (C) samples.

initial reactant concentrations were $c_{\mathrm{i}}\left(\mathrm{Ca}^{2+}\right)=7.5 \mathrm{mmol} \mathrm{dm}^{-3}$ and $c_{\mathrm{i}}\left(\mathrm{C}_{2} \mathrm{O}_{4}{ }^{2-}\right)=4 \mathrm{mmol} \mathrm{dm}^{-3}$, and the temperature $t=$ $36.5^{\circ} \mathrm{C}$ but initial pH changed from 5.6 (5a system) to 6.5 (5b system) and finally to 7.5 (5c system), only diffraction peaks of COM crystals were detected and assigned to the (101) , (020), (202) , (112) and (130) planes ${ }^{[23]}$ respectively, indicating the formation of pure COM in these precipitates. This is in agreement with the results of FT-IR spectra analysis, as well as with the results of TGA. As can be seen from Figure $3 \mathrm{~A}$ increase of initial $\mathrm{pH}$ caused a significant change in peak intensity assigned to (101) and (020) planes. The peak intensity of the (101) and (020) planes, for samples from selected precipitation systems $(5 a-c)$, increased with the increase of initial $\mathrm{pH}$, as seen from Figure $3 \mathrm{~A}$ for (101) plane and from inset of Figure $3 \mathrm{~A}$ for (020) planes.

More specifically, the change in peak intensity was more pronounced in the case of (101) than in the case of (020). An increase in peak intensity indicates that (101) and (020) planes will be more expressed at the highest $\mathrm{pH}$ used. 
Based on the crystal structure analysis, the (101) planes are relatively rich in $\mathrm{Ca}^{2+}$ ions and the (020) planes are relatively rich in oxalate ions. ${ }^{[24]}$ With the increase of initial $\mathrm{pH}$ from 5.6 to 7.5 concentration of $\mathrm{OH}^{-}$ions increases around 100 times. It can be speculated that this excess of $\mathrm{OH}^{-}$ions can be preferentially adsorbed on positively charged (101) COM plane resulting in its stabilization during COM growth and this could be reflected in the changes in the morphology of crystals during growth at initial pH 7.5 (highest concentration of $\mathrm{OH}^{-}$in conducted experiments).

Some authors have also studied the growth of COM concerning the intensity ratio of the $(\overline{101)}$ and (020) planes, but so far, no research has been conducted exclusively on additive-free systems in the conditions of nearly the same initial supersaturation. In systems with additives, it has been observed that the more negative end of the additive prefers to bind to the more positive (101) planes and affect morphology. ${ }^{[25-27]}$

\section{Morphological Characteristics}

The influence of reactant concentration $\left(\mathrm{c}_{\mathrm{i}}\left(\mathrm{Ca}^{2+}\right)\right.$ and $\left.\mathrm{c}_{\mathrm{i}}\left(\mathrm{C}_{2} \mathrm{O}_{4}{ }^{2-}\right)\right)$, the reaction temperature and initial $\mathrm{pH}$ have also been estimated by identifying the changes in morphology and crystal size of the precipitated calcium oxalate separated from the suspension at the predetermined time. Thus, Figure 4 shows the light microscopy images of all precipitated samples.

In all investigated systems, exclusive precipitation of dendritic structure with rough edges and tips was observed, except in the systems 1 and $2 b$, where irregular, platelet aggregated crystals with a small proportion of dendritic structure were formed.

With the increase of the systems' pH $5.6>6.5>7.5$ more branched dendritic forms were observed. In the study by He et al. ${ }^{[4]}$ it has been reported that most crystallites in healthy urine samples are spheroidal and well dispersed but that the major particles in lithogenic urine exhibit sharply angled edges and tips. Also, Wei et al..[27] reported that the dendritic structure of COM can be closely related to supersaturation and the concentration ratio of calcium to oxalate. Mostly, the dendritic structure of COM has been described in the systems with higher concentrations of oxalate and calcium. ${ }^{[27]}$

In our precipitation experiments, it was observed that at nearly the same initial supersaturation $\left(S_{\mathrm{COM}}=\right.$ $30.73 \pm 2.08$; Table 1$)$ and at defined $\mathrm{pH}(\mathrm{pH}=6.5)$, the crystal size is affected by temperature and calcium concentration. With increasing temperature, there is an increase in the size of COM crystals at all investigated calcium concentrations (Figure 4). In systems with the lowest calcium concentration, $c\left(\mathrm{Ca}^{2+}\right)=5 \mathrm{mmol} \mathrm{dm}^{-3}$, the measured crystal sizes were as follows: $10.60 \pm 2.23 \mu \mathrm{m}$ at $25^{\circ} \mathrm{C}, 11.96 \pm 3.31$ at $36.5^{\circ} \mathrm{C}$ and $17.97 \pm 4.80 \mu \mathrm{m}$ at $48^{\circ} \mathrm{C}$ (Figure 5). Other authors have also observed that the higher reaction temperature resulted in a larger crystal size. ${ }^{[28,29]}$ From the Figure 5 it can be observed that at the same temperature, calcium concentration plays a significant role in crystal size. With the increase of the concentration of calcium, crystal size decreases (Figure 5c).

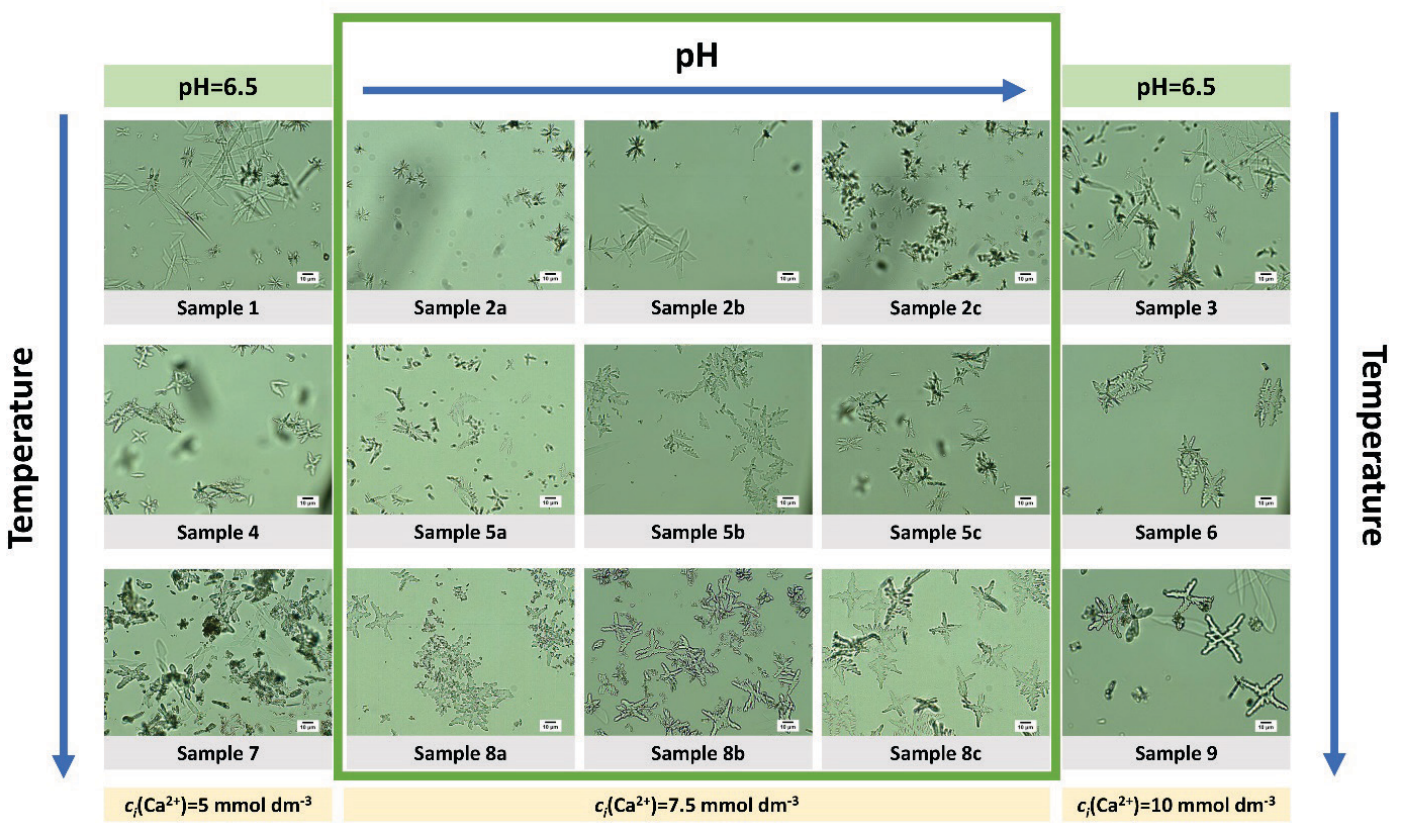

Figure 4. Light microscopy images of COM precipitates in all systems (SP objective 40X). 

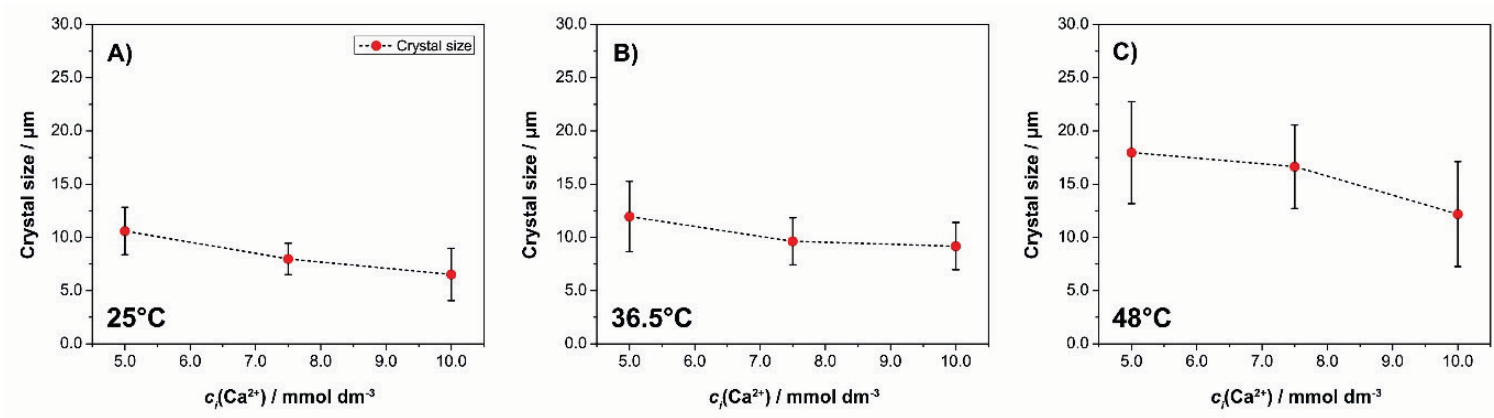

Figure 5. Size of $\mathrm{COM}$ crystals at different initial calcium concentration, $\mathrm{c}_{\mathrm{i}}\left(\mathrm{Ca}^{2+}\right)$. The crystals were formed in the systems with fixed oxalate concentration, $c_{\mathrm{i}}\left(\mathrm{C}_{2} \mathrm{O}_{4}{ }^{2-}\right)=4.0 \mathrm{mmol} \mathrm{dm}{ }^{-3}, \mathrm{pH}=6.5$ and under different temperature: $t=25^{\circ} \mathrm{C}(\mathrm{A}), t=36.5^{\circ} \mathrm{C}(\mathrm{B})$ and $t=48^{\circ} \mathrm{C}(\mathrm{C})$.

To improve comprehension of possible changes in COM crystal morphology under different temperatures and different initial calcium concentration precipitates prepared in the selected systems at $\mathrm{pH}=6.5$ (sample 1, 2b, 3, 5b and $8 b)$ were analyzed with SEM technique.

SEM micrographs revealed morphology differences caused by the changes in the reactant concentrations and applied temperature. These results agree with light microscopy analysis. With the increase of initial calcium concentration, but constant temperature (Figure 6A; sample $1,2 \mathrm{~b}$ and 3 ) the obtained crystals resulted in a smaller size and the edges were more rounded. It can also be observed that the calcium concentration affects the crystal thickness; since the $c_{\mathrm{i}}\left(\mathrm{Ca}^{2+}\right)=5 \mathrm{mmol} \mathrm{dm}^{-3}$

A)

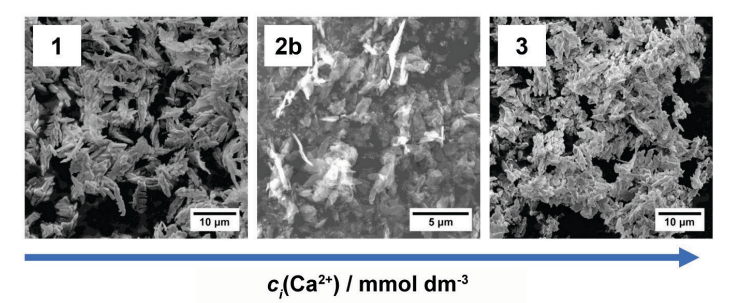

B)

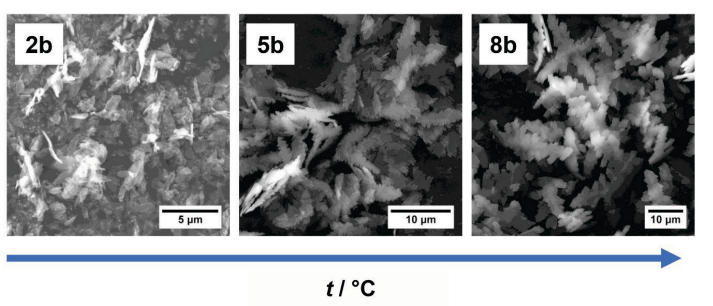

Figure 6. SEM images of samples prepared at $\mathrm{pH}=6.5$ in the systems: (A) at $t=25^{\circ} \mathrm{C}$ and different initial calcium concentration: $c_{i}\left(\mathrm{Ca}^{2+}\right)=5 \mathrm{mmol} \mathrm{dm}{ }^{-3}($ system 1$), c_{i}\left(\mathrm{Ca}^{2+}\right)=7.5$ $\mathrm{mmol} \mathrm{dm}{ }^{-3}$ (system $2 \mathrm{~b}$ ) and $\mathrm{c}_{\mathrm{i}}\left(\mathrm{Ca}^{2+}\right)=10 \mathrm{mmol} \mathrm{dm}^{-3}$ (system 3 ) and (B) at constant initial calcium concentration $c_{\mathrm{i}}\left(\mathrm{Ca}^{2+}\right)=$ $7.5 \mathrm{mmol}$ and different temperature: $t=25^{\circ} \mathrm{C}$ (system $2 \mathrm{~b}$ ), $t=36.5^{\circ} \mathrm{C}$ (system $5 \mathrm{~b}$ ) and $t=48.0^{\circ} \mathrm{C}$ (system $8 \mathrm{~b}$ ). concentration produced thinner, while higher concentrations of calcium $\left(c_{\mathrm{i}}\left(\mathrm{Ca}^{2+}\right)=7.5\right.$ and $\left.10 \mathrm{mmol} \mathrm{dm}{ }^{-3}\right)$ produced thicker crystals. In addition, Sun et al.[25] have observed a similar trend in their work. It has been reported that at higher calcium concentrations $\left(c_{i}\left(\mathrm{Ca}^{2+}\right)=40\right.$ and 20 $\mathrm{mmol} \mathrm{dm}^{-3}$ ) thicker crystals were obtained. By increasing the applied temperature (Figure $6 \mathrm{~B}$; sample $2 \mathrm{~b}, 5 \mathrm{~b}$ and $8 \mathrm{~b}$ ) the crystals were larger and have grown in many directions and their edges were more serrated. In the study by Wei et al. ${ }^{[27]}$, thin, plate-like crystals with serrated edges at $25^{\circ} \mathrm{C}$ were obtained, and with increasing reaction temperature to $40{ }^{\circ} \mathrm{C}$, the morphology of crystals have changed to "crisscross"- type with a tendency to aggregate.

\section{CONCLUSIONS}

The studies of calcium oxalate monohydrate (COM), one of the predominant constituents of kidney stones, and the thermodynamically stable phase of calcium oxalate are still receiving tremendous attention. Most of the research concerning the inhibition effect on the COM formation and crystal properties was conducted in the systems with or without additives. Our work contributes to the research of additive-free systems in conditions of nearly the same initial supersaturation $\left(S_{\text {COM }}=30.73 \pm 2.08\right)$. In such system we presented the influence of thermodynamic parameters; $\mathrm{pH}(\mathrm{pH}=5.6,6.5$ or 7.5$)$, calcium concentration $(5 \mathrm{mmol}$ $\left.\mathrm{dm}^{-3} \leq c_{\mathrm{i}}\left(\mathrm{Ca}^{2+}\right) \leq 10 \mathrm{mmol} \mathrm{dm}^{-3}\right)$ and temperature $\left(t=25^{\circ} \mathrm{C}\right.$, $t=36.5^{\circ} \mathrm{C}$ and $t=48{ }^{\circ} \mathrm{C}$ ). These wide ranges of selected conditions included values which closely mimic the physiological conditions related to biological systems and kidney stone formation.

In all systems exclusively COM phase precipitated. The investigated parameters $(\mathrm{pH}$, temperature and initial calcium concentration) strongly affect the structural and morphological characteristics of formed COM crystals. In the systems with constant $\mathrm{pH}$ and temperature, the increase in initial calcium concentration favors the formation of the full dendritic morphology of COM and crystal size reduction. An 
increase in the $\mathrm{pH}$ value of the system causes the formation of more branched dendritic structures and the expression of (101) and (020) planes. In the systems with constant $\mathrm{pH}$ and initial calcium concentration, the temperature increase caused the increase in COM crystal size.

Our experiments showed that under well-defined conditions of nearly the same initial supersaturation COM crystals are formed, and their structural and morphological properties reflect the influence of individual thermodynamic parameters $(\mathrm{pH}$, calcium concentration and temperature), but also their synergic effect. The applied conditions could be suitable for future studies of synthesis and mechanism of COM precipitation in the presence of molecules related to kidney stone formation.

Acknowledgment. I. D. M. acknowledges financial support of the Center of Excellence for Advanced Materials and Sensing Devices (ERDF Grant No. KK.01.1.1.01.0001).

M. M. K., A. S., D. G. and B. V. acknowledge the financial support of the Department of Chemistry (PPUZN_MMK).

\section{REFERENCES}

[1] A. E. Nielsen, J. Christoffersen, Biological Mineralization and Demineralization, Springer. 1982, 37-77.

https://doi.org/10.1007/978-3-642-68574-3_4

[2] G. H. Nancollas, Biological Mineralization and Demineralization, Springer. 1982, 1-4.

https://doi.org/10.1007/978-3-642-68574-3_1

[3] B. Hess, R. L. Ryall, J. P. Kavanagh, S. R. Khan, D. J. Kok, A. L. Rodgers, H. G. Tiselius, Eur. Urol. 2001, 40, 220-230. https://doi.org/10.1159/000049776

[4] J.-Y. He, D. Ping, J. M. Ouyang, IEEE Trans. Nanobiosci. 2010, 9, 156-163.

https://doi.org/10.1109/TNB.2010.2045510

[5] W. G. Robertson, M. Peacock, B. E. C. Nordin, The Lancet 1969, 294, 21-24.

https://doi.org/10.1016/S0140-6736(69)92598-7

[6] V. Romero, H. Akpinar, D. G. Assimos, Rev Urol. 2010, 12, 86-96.

[7] G. H. Nancollas, Z. J. Henneman, Urol Res 2010, 38, 277-280.

https://doi.org/10.1007/s00240-010-0292-3

[8] Y. Hara, J. Ypn. Urol. 1994, 85, 1322-1326.

https://doi.org/10.5980/jpnjurol1989.85.1322

[9] J. Manissorn, K. Fong-ngern, P. Peerapen, V. Thongboonkerd, Sci. Rep. 2017, 7, 1798 https://doi.org/10.1038/s41598-017-01953-4

[10] D. Asokan, P. Kalaiselvi, S. Muhammed Farooq, P. Varalakshmi, Urol. Res. 2004, 32, 357-361. https://doi.org/10.1007/s00240-004-0430-x

[11] S. R. Khan, R. L. Hackett, J. Urol. 1993, 150, 239-245. https://doi.org/ 10.1016/s0022-5347(17)35454-x
[12] B. B. Tomažić, G. H. Nancollas, J. Urol. 1982, 128, 205208. https://doi.org/ 10.1016/s0022-5347(17)52819-0

[13] V. Thongboonkerd, T. Semangoen, S. Chutipongtanate, Clin. Chim. Acta. 2006, 367, 120-131. https://doi.org/10.1016/j.cca.2005.11.033

[14] A. Šter, S. Šafranko, K. Bilić, B. Marković, D. Kralj, Urolithiasis 2018, 46, 243-256. https://doi.org/10.1007/s00240-017-0991-0

[15] C. Conti, M. Casati, C. Colombo, M. Realini, L. Brambilla, G. Zerbi, Spectrochim. Acta A Mo.I Biomol. Spectrosc. 2014, 128, 413-419.

https://doi.org/10.1016/j.saa.2014.02.182

[16] M. L. Green, R. W. Freel, M. Hatch, Kidney Int. 2005, 68, 2629-2638.

https://doi.org/10.1111/j.1523-1755.2005.00735.x

[17] F. L. Coe, J. H. Parks, J. R. Asplin, N. Engl. J. Med. 1992, 327, 1141-1152.

https://doi.org/10.1056/NEJM199210153271607

[18] T. Alelign, B. Petros, Adv Urol. 2018, 2018, 3068365. https://doi.org/10.1155/2018/3068365

[19] A. Stanković, S. Šafranko, K. Jurišić, I. Balić, J. Bijelić, S. Jokić, M. Medvidović-Kosanović, Chemical Papers 2020, 74, 3279-3291. https://doi.org/10.1007/s11696-020-01157-7

[20] A. Stanković, S. Šafranko, J. Kontrec, B. Njegić Džakula, D. M. Lyons, B. Marković, D. Kralj, Cryst. Res. Technol. 2019, 54, 1-11. https://doi.org/10.1002/crat.201800210

[21] B. Njegić-Džakula, G. Falini, Lj. Brečević, Ž. Skoko, D. Kralj, J. Colloid. Interf. Sci. 2010, 343, 553-563. https://doi.org/10.1016/j.jcis.2009.12.010

[22] T. Echigo, M. Kimata, A. Kyono, M. Shimizu, T. Hatta, Mineral. Mag. 2005, 69, 77-88. https://doi.org/10.1180/0026461056910235

[23] M. King, W. F. Mcclure, L. C. Andrews, Powder diffraction file alphabetic index, inorganic phasesorganic phases, International center for diffraction data, Newtown Square, PA, 1992.

[24] L. Tunik, H. Furedi-Milhofer, N. Garti, Langmuir 1998, 14, 3351-3355. https://doi.org/10.1021/la9708041

[25] X.-Y. Sun, C.-Y. Zhang, P. Bhadja, J.-M. Ouyang, CrystEngComm 2018, 20, 75-87. https://doi.org/10.1039/c7ce01912b

[26] X.-Y. Sun, J.-M. Ouyang, M. Xu, CrystEngComm 2016, 18, 5463-5473. https://doi.org/10.1039/C6CE00697C

[27] X. Wei, J. Yang, Z. Li, Y. Su, D. Wang, Coll. Surf. A Physicochem. Eng. Asp. 2012, 401, 107-115. https://doi.org/10.1016/j.colsurfa.2012.03.034

[28] X. Y. Sun, J.-M. Ouyang, A.-J. Liu, Y.-M. Ding, Q.-Z. Gan, J. Mater. Sci. Eng. 2015, 57, 147-156. https://doi.org/10.1016/j.msec.2015.07.032

[29] J. M. Ouyang, H. Zheng, S. P. Deng, J. Cryst. Growth 2006, 293, 118-123. https://doi.org/10.1016/j.jcrysgro.2006.05.008 